\title{
Karakteristik Morfologi Polen Sebagai Sumber Pakan Lebah Trigona sp. di Desa Serang, Purbalingga
}

\author{
Salma Fauzia*, Sukarsa, Wiwik Herawati \\ Fakultas Biologi, Universitas Jenderal Soedirman \\ Jalan dr. Suparno 63 Purwokerto 53122 \\ *Email: salmafauzia17.sf@gmail.com
}

Rekam Jejak Artikel:

Diterima : 27/08/2019

Disetujui : 13/11/2019

\begin{abstract}
Highland areas have good potential as plantation and agriculture, which also supports the growth of some kinds of the honey bee, such as Trigona sp. The huge amount of food sources increases honey production by the Trigona. Pollens, the source of protein, and nectar are the source of carbohydrates for the Trigona. The variation of Trigona's food may be identified through the character of the pollen's morphology that is brought by the bees inside the hive and is compared to the character of other pollen's morphology from the flowers around the hive. The objective of this research is to discover the pollen's morphology structures from the flowers around the beehive and the pollens inside the Trigona bees' hive as their source of food. This research is conducted in Serang, Purbalingga. This research is done by using survey method as the pollens' sample is taken from the flowers around the beehives and inside the hives, and the samples are prepared using the acetolysis method. The variables are the characters of the pollen morphology with the following parameters: unit, shape, size, aperture, and pollens ornamentation. The obtained data were analyzed descriptively. Based on the research of 17 families in 23 plant species around the Trigona bee hive, there were various morphological characteristics, namely monad pollen unit, spheroidal to prolate form, small to large size, monosulcate, monoporate, triporate, tricolpate, tricolate, tetracolpate and hexacolpate apertures. clavate, scabrate, reticulate, bireticulate, baculate, psilate, echinate and scabrate ornamentation. The observation for the pollens inside the hives shows there are 11 pollen species, and 10 of them are identical with the pollens outside the hives. All observed pollens have a monad pollen unit. Meanwhile the other characteristics vary in spheroidal to prolate size, kecil to large size, monosulcate, monoporate, triporate, tricolpate, tricolporate, tetracolpate, and hexacolpate aperture, also calvate, scabrate, reticulate, bireticulate, baculate, psilate, echinate, and scabrate ornamentation.

Keywords: Flowers, Morphological Characteristics, Pollen, Trigona sp
\end{abstract}

\section{Abstrak}

Wilayah dataran tinggi memilikiBerpotensi untuk dimanfaatkan sebagai lahan perkebunan, pertanian, dan mendukung perkembangan beberapa jenis lebah penghasil madu diantaranya adalah Trigona sp. Kelimpahan sumber pakan yang tinggi dapat meningkatkan produksi madu lebah Trigona. Polen merupakan sumber protein, sedangkan nektar berperan sebagai sumber karbohidrat dalam pakan Trigona. Keragaman jenis pakan Trigona dapat diidentifikasi dari karakter morfologi polen yang dibawa oleh lebah ke dalam sarang serta dibandingkan dengan karakter morfologi polen pada beberapa bunga di sekitar sarang. Tujuan dari penelitian ini adalah untuk mengetahui struktur morfologi polen dari bunga yang ada di sekitar sarang dan polen yang ada di sarang lebah Trigona. Penelitian ini dilakukan di Desa Serang, Kecamatan Karangreja, terletak di Kabupaten Purbalingga. Penelitian dilakukan dengan metode survei, sampel polen diambil dari bunga yang ada di sekitar sarang dan yang ada di dalam sarang, sampel dipreparasi dengan menggunakan metode asetolisis. Variabel yang digunakan adalah karakter morfologi polen dengan parameter berupa: unit, bentuk, ukuran, apertura, dan ornamentasi polen. Data yang diperoleh dianalisis secara deskriptif. Berdasarkan hasil penelitian dari 17 familia yang tercakup dalam 23 spesies tumbuhan yang ada di sekitar sarang lebah Trigona sp. didapatkan hasil karakter morfologi yang bervariasi. Unit polen monad, bentuk polen spheroidal sampai prolate, ukuran kecil sampai besar, apertura monosulcate, monoporate, triporate, tricolpate, tricolporate, tetracolpate dan hexacolpate serta ornamentasi clavate, scabrate, reticulate, bireticulate, baculate, psilate, echinatedan scabrate. Pengamatan polen di dalam sarang menunjukkan adanya 11 spesies polen yang dapat diamati dan 10 diantaranya identik dengan polen dari bunga di sekitar sarang. Seluruh polen yang diamati memiliki unit polen monad sedangkan karakter lainnya bervariasi dari bentuk polen spheroidal sampai prolate, ukuran kecil sampai besar, apertura monosulcate, monoporate, tricolporate, dan tricolpate serta ornamentasi scabrate, reticulate, psilate, scabrate dan echinate.

Kata kunci: Bunga, Karakter Morfologi, Polen,Trigona sp. 


\section{PENDAHULUAN}

Desa Serang, Kecamatan Karangreja, terletak di Kabupaten Purbalingga memiliki luas wilayah keseluruhan 3.052,94 ha. Desa ini berada pada ketinggian sekitar $800-1.300 \mathrm{mdpl}$. Curah hujan rata-rata tiap bulannya antara $235-274 \mathrm{~mm}$ dengan suhu 18-24 oC. Keadaan iklim seperti ini cocok untuk dijadikan lahan pertanian hortikultura dan perkebunan. Penggunaan lahan tegalan dan kebun oleh masyarakat di desa Serang mencapai 43,26\% yaitu sekitar 1.245,07 ha. Komoditas unggulan yang dibudidayakan di desa ini adalah stroberi dan kubis (Haryanto, 2017).

Banyaknya lahan pertanian dan perkebunan di desa ini mendukung perkembangan lebah Trigona (Trigona sp). Genus Trigona memiliki peran penting dalam proses penyerbukan bunga (Pratama et al., 2018). Di Indonesia dan Malaysia telah ditemukan 17 spesies lebah Trigona yang dibedakan berdasarkan panjang probosisnya, sehingga mempunyai kecenderungan mengunjungi bunga yang berbeda antar spesies (Widhiono et al., 2016).

Lebah Trigona mempunyai kebiasaan mengunjungi bunga yang berukuran kecil dan berbentuk pipih, dengan posisi nektar dan polen yang tidak terlindungi (Widhiono et al., 2016). Berdasarkan hasil penelitian Sulistia et al. (2018) pakan lebah Trigona berasal dari berbagai spesies tumbuhan yaitu tumbuhan hutan, perkebunan, buahbuahan, tanaman pangan dan sayuran, tanaman hias dan semak. Penelitian Nugroho \& Soesilohadi (2014) bahwa tumbuhan yang menjadi sumber pakan lebah Trigona di Gunung Kidul berasal dari tumbuhan pepaya (Carica papaya), kelengkeng (Dimocarpus longan), kenikir (Cosmos caudatus), dan didominasi oleh tumbuhan dari Familia Poaceae yaitu jagung (Zea mays) dan padi (Oriza sativa). Di Indonesia lebah Trigona belum banyak diketahui manfaatnya oleh masyarakat. Salah satunya di Desa Serang Kabupaten Purbalingga, kurangnya pengetahuan mengenai lebah ini serta sumber pakannya menjadi salah satu faktor rendahnya minat masyarakat dalam budidaya lebah Trigona di daerah ini.

Hal yang menjadi daya tarik bagi lebah Trigona untuk mengunjungi bunga adalah warna, bau dan ukuran polen (Ramadhani, 2016). Lebah dan tumbuhan berbunga memiliki hubungan yang saling menguntungkan yaitu tumbuhan menyediakan nektar dan polen sebagai sumber pakan, sedangkan lebah membantu terjadinya proses penyerbukan pada bunga (Agussalim et al., 2017). Polen merupakan alat perkembangbiakan jantan yang dihasilkan oleh tumbuhan spermatophyta (Azizah et al., 2016). Dinding polen terdiri dari dua lapisan yaitu eksin (lapisan luar) dan intin (lapisan dalam). Eksin tersusun atas sporopollenin, sedangkan intin tersusun atas selulosa. Struktur dan ornamentasi dari eksin inilah yang memberikan gambaran morfologi polen secara mikroskopis sehingga memungkinkan untuk dapat diidentifikasi (Kapp, 1969).

Menurut Tjitrosoepomo (2002) karakter struktur polen yang bervariasi dapat digunakan untuk identifikasi dan interpretasi filogenetik. Bentuk yang bermacam-macam ini penting dari segi taksonomi, dan dapat digunakan untuk identifikasi tumbuhan. Selain itu, Faegri \& Iversen (1989) menyebutkan bahwa polen dapat digunakan juga untuk identifikasi tumbuhan karena memiliki struktur dan ornamentasi eksin yang khas dan terawetkan karena mengandung sporopollenin yang resisten terhadap bahan organik serta lingkungan yang ekstrim. Variasi morfologi polen yang dapat diamati meliputi unit polen, simetri polen, polaritas polen, bentuk polen, tipe apertura dan ornamentasi eksin (Erdtman, 1952). Dengan demikian perlu dilakukan identifikasi struktur morfologi polen dari bunga yang ada di sekitar sarang lebah Trigona sp. dan morfologi polen yang dibawa oleh lebah. Penelitian ini diharapkan dapat memberikan informasi ilmiah yang bermanfaat dalam menentukan spesies tumbuhan sebagai sumber pakan lebah Trigona sp. di Desa Serang Purbalingga.

\section{MATERI DAN METODE}

Bahan yang digunakan ada bunga disekitar sarang lebah Trigona sp. beserta polennya, polen yang ada di dalam sarang lebah Trigona sp. asam asetat glasial, asam sulfat pekat, akuades, safrain dan gliserin jelly. Alat yang digunakan adalah, object glass, cover glass, pipet tetes, waterbath, mikrometer objektif, mikrometer okuler, tabung sentrifus, sentrifugator, dan mikroskop cahaya.

Pengambilan sampel dilaksanakan di Desa Serang, Kecamatan Karangreja, Kabupaten Purbalingga. Koordinat S7 ${ }^{\circ} 14^{\prime} \quad 10,3$ E109 ${ }^{\circ} 6^{\prime}$ 14,9. Sampai S7 ${ }^{\circ} 14^{\prime} 2,1$ E109 $16^{\prime}$ 45,0. Preparasi dan identifikasi polen dilakukan di Fakultas Biologi Universitas Jenderal Soedirman, Purwokerto. Penelitian ini dilakukan dengan metode survey dengan teknik random sampling, sampel polen dikumpulkan dari bunga sekitar sarang dan yang terdapat didalam sarang, kemudian dipreparasi menggunakan metode asetolisis. Struktur morfologi polen diamati dengan mikroskop. Variabel yang digunakan adalah karakter morfologi polen dengan parameter karakteristik morfologi polen berupa: unit, bentuk, ukuran, apertura, dan ornamentasi polen.

\section{Pengambilan sampel}

Bunga yang berada di sekitar sarang lebah pada radius $\pm 200 \mathrm{~m}$ diambil, dimasukan ke dalam plastik bening dan diberi label. Pengambilan sampel polen dari bunga dilakukan dengan memotong antera/kepala sari dari bunga tersebut kemudian dimasukkan ke dalam botol flakon yang telah berisi asam asetat glasial dan diberi label. Pengambilan 
polen dari sarang lebah dilakukan dengan membuka bagian atas sarang yang mengandung polen. Polen dikumpulkan lalu dimasukkan ke dalam botol flakon yang telah berisi asam asetat glasial dan diberi label.

\section{Identifikasi tumbuhan}

Bunga disekitar sarang yang diambil polennya diamati ciri-ciri morfologinya, setelah itu diidentifikasi menggunakan buku Flora of Java oleh Backer \& Brink (1968), Flora oleh Steenis (1987), Jenis-Jenis Tumbuhan Bawah oleh Karyati \& Adhi (2018).

\section{Preparasi sampel polen}

Preparasi sampel polen dilakukan dengan metode asetolisis menurut Erdtman (1943) yaitu dilakukan proses fiksasi dengan polen dimasukkan ke dalam botol flakon yang telah diisi asam asetat glasial $45 \% \pm 5 \mathrm{ml}$ selama 24 jam. Bahan kemudian dipindahkan ke dalam tabung sentrifus, diberi 1-2 tetes asam sulfat pekat secara perlahan melalui dinding tabung untuk proses hidrolisis. Tabung dipanaskan dalam waterbath, kemudian bahan disentrifus, supernatan dibuang dan endapan dicuci dengan akuades. Pencucian dilakukan sebanyak 3x setiap pencucian dilakukan sentrifus. Dilanjutkan dengan proses pewarnaan menggunakan safranin dalam glyserin jelly didiamkan selama \pm 10 menit. Polen yang telah terwarnai diletakkan di atas object glass dan ditutup cover glass, kemudian diamati.

\section{Pengukuran polen}

Panjang aksis polar dan diameter ekuatorial diukur dengan menggunakan mikrometer okuler pada mikroskop cahaya dengan perbesaran 400x untuk mengetahui bentuk dan ukuran polen. Bentuk polen dapat diketahui dengan membandingkan panjang aksis polar dan diameter ekuatorial (Erdtman, 1952). Menggunakan rumus

$$
\frac{\mathrm{P}}{\mathrm{E}} \times 100
$$

Keterangan:

$\mathrm{P}=$ indeks polar

$\mathrm{E}=$ diameter ekuatorial

Erdtman (1952) mengelompokan bentuk polen berdasarkan indeks P/Ex100 sebagai berikut, Peroblate $(<50 \mu \mathrm{m})$, Oblate $(50-75 \mu \mathrm{m})$, Sub-oblate (75-88 $\mu \mathrm{m})$, Oblate-spheroidal (88-99 $\mu \mathrm{m})$, Spheroidal $(100 \mu \mathrm{m})$, Prolate-spheroidal (101-114 $\mu \mathrm{m})$, Sub-prolate $(114-133 \mu \mathrm{m})$, Prolate (133-200 $\mu \mathrm{m})$ dan Per-prolate $(>200 \mu \mathrm{m})$. Erdtman (1952) juga mengelompokan bentuk polen berdasarkan ukuran aksis terpanjang sebagai berikut, Very small $(<10 \mu \mathrm{m})$, Kecil $(10-25 \mu \mathrm{m})$, Medium $(25-50 \mu \mathrm{m})$, Large $(50-100 \mu \mathrm{m})$, Very large $(100-200 \mu \mathrm{m})$ dan Gigantic (>200 $\mu \mathrm{m})$.

\section{Pengamatan polen}

Preparat polen diamati menggunakan mikroskop cahaya pada perbesaran 400x. Diamati unit polen, tipe apertura dan ornamentasi. diidentifikasi menggunakan buku Erdtman (1943 dan 1952), Faegri \& Iversen (1989), Kapp (1969), dan Moore et al., (1991).

\section{Identifikasi polen}

Diamati unit, tipe apertura dan ornamentasi polen kemudian diidentifikasi dengan cara mengamati karakteristik morfologi polen dari masing-masing bunga, hasil dibandingkan dengan pustaka oleh Erdtman (1943 dan 1952) dan Faegri \& Iversen (1989). Kemudian karakteristik morfologi polen yang ada di dalam sarang diamati lalu dibandingkan dengan karakteristik polen dari masing-masing bunga yang telah diidentifikasi, sehingga diketahui tumbuhan penghasilnya.

Data dianalisis secara deskriptif untuk mengetahui struktur morfologi polen dari bunga yang ada disekitar sarang dan polen yang ada di sarang lebah Trigona sp.

\section{HASIL DAN PEMBAHASAN}

Berdasarkan hasil identifikasi didapatkan 23 spesies tumbuhan sumber pakan lebah Trigona yang termasuk ke dalam 17 familia terdapat disekitar sarang lebah Trigona di Desa Serang, Purbalingga. Tumbuhan yang ditemukan di sekitar sarang antara lain Pachystachys lutea dari familia Acanthaceae, Daucus carota dari familia Apiaceae, Dahlia pinnata, Tagetes erecta, Cosmos sulphureus, Emilia sonchifolia, Zinnia elegans dan Praxelis clematidea dari familia Asteraceae. Impatiens balsamina dari familia Balsaminaceae, Begonia cucullata dari familia Begoniaceae, Brassica juncea dari familia Brassicaceae, Cleome houtteana dari familia Capparaceae, Chrysothemis pulchella dari familia Gesneriaceae, Hydrangea macrophylla dari familia Hydrangeaceae, Trimezia longifolia dari familia Iridaceae, Salvia splendens dan Clerodendrum thomsoniae dari familia Lamiaceae. Cuphea hyssopifolia dari familia Lythraceae, Tibouchina urvilleana dari familia Melastomataceae, Zea mays dari familia Poaceae, Persicaria capitata dari familia Polygonaceae, Rosa sp. dari familia Rosaceae dan Tropaelum majus dari familia Tropaeolaceae.

Pachystachys lutea dari familia Acanthaceae memiliki karakteristik polen memiliki unit monad, bentuk prolate ukuran besar aperture tricolporate serta tipe ornamentasi reticulate Sesuai dengan Erdtman (1952) yang menyatakan bahwa polen dari familia Acanthaceae memiliki bentuk peroblate sampai prolate, apertura bervariasi 3-8 colpate, 3-5 colporate, 2-4 porate bahkan beberapa pseudocolpi. Daucus carota dari Familia Apiaceae memiliki karakteristik morfologi polennya berupa unit polen monad, ukuran polen besar, bentuk spheroidal, 
apertura tricolporate dan ornamentasi regulate. Hasil penelitian Avila et al. (2016) menunjukkan hasil bahwa polen dari familia Apiaceae memiliki unit polen monad, ukuran polen biasanya sedang, apertura tricolporate dengan colpi yang panjang.

Tumbuhan anggota familia Asteraceae yang didapatkan ada 7 spesies yaitu Dahlia pinnata, Tagetes erecta, Cosmos sulphureus, Emilia sonchifolia, Zinnia elegans dan Praxelis clematidea. Anggota familia asteraceae memiliki karakteristik morfologi polen yang miripyaitu unit polen monad, dan tipe ornamentasi echinate, sedangkan bentuk, ukuran serta apertura nya berbeda. Perveen (1999) menyatakan bahwa anggota familia Asteraceae memiliki bentuk polen bulat hingga bulat memanjang. Tipe apertura umumnya tricolpate atau tricolporate. Memiliki tipe ornamentasi echinate atau berduri, biasanya duri pendek, tebal pada bagian pangkal, dan hampir berbentuk kerucut Erdtman (1954). Pernyataan tersebut juga didukung oleh penelitian yang dilakukan oleh Das dan Mukherjee (2013) yang menyatakan bahwa ornamentasi eksin dari anggota familia Asteraceae berupa echinate yaitu bentukan seperti duri.

Dahlia pinnata memiliki polen bentuk prolatespheroidal, dengan ukuran sedang memiliki tipe apertura monoporate. Cosmos sulphureus memiliki polen bentuk prolate-spheroidal dengan ukuran sedang dan tipe apertura tricolpate. Tumbuhan Tagetes erecta yang ditemukan disekitar sarang terdiri dari dua jenis bunga, dibedakan dari banyak sedikitnya bunga cakram. T. erecta bunga merah kuning, memiliki bunga cakram yang lebih banyak dibandingkan $T$. erecta bunga merah. Perbedaan struktur morfologi polen pada kedua bunga ini terdapat pada bentuk polen, $T$. erecta bunga merah kuning memiliki polen dengan bentuk spheroidal, sedangkan $T$. erecta bunga merah memiliki polen dengan bentuk prolate-spheroidal. Keduanya memiliki ukuran polen sedang dan tipe apertura nya tricolpate. Emilia sonchifolia memiliki polen bentuk prolate-spheroidal dengan ukuran sedang dan tipe apertura tricolporate. Zinnia elegans memiliki polen bentuk spheroidal dengan ukuran sedang dan tipe apertura tricolpate. Praxelis clematidea memiliki bentuk polen prolate-spheroidal dengan ukuran kecil dan tipe apertura tricolporate.

Impatiens balsamina dari familia Balsaminaceae memiliki unit polen monad, bentuk prolate, ukuran sedang dan tipe apertura tertracolpate serta tipe ornamentasi reticulate. Sesuai dengan hasil penelitian Sukarsa et al., (2002). Bahwa Impatiens balsamina memiliki unit polen monad, bentuk peroblate, apertura tetrakolpate dan ornamentasi reticulate. Begonia cucullata dari familia Begoniaceae memiliki unit polen monad, bentuk prolate, ukuran kecil memiliki tipe aperture tricolpate serta tipe ornamentasi psilate. Sesuai dengan Erdtman (1952) bahwa anggota familia begoniaceae memiliki polen dengan bentuk prolate sampai perprolate, berukuran kecil dan tipe apertura tricolpate atau tricolporate. Brassica juncea dari familia Brassicaceae memiliki unit polen monad, bentuk prolate-spheroidal dengan ukuran kecil, memiliki tipe apertura tricolpate dan tipe ornamentasi clavate. Sesuai dengan penelitian Wulandari et al. (2017) polen familia Brassicaceae memiliki bentuk prolate sampai oblate dan memiliki apertuta tricolpate.

Cleome houtteana dari familia Capparaceae memiliki karakteristik polennya unit monad, bentuk prolate-spheroidal dengan ukuran sedang memiliki tipe apertura tricolporate dan tipe ornamentasi baculate. Sesuai dengan hasil penelitian Rismayanti et al. (2015) polen familia capparaceae memiliki bentuk polen prolate-spheroidal, ukuran sedang, serta memiliki aperture tricolporate. Chrysothemis pulchella dari familia Gesneriaceae. memiliki polen unit monad, bentuk prolate dengan ukuran sedang memiliki tipe apertura tricolporate dan tipe ornamentasi scabrate. Erdtman (1952) menyatakan bahwa polen familia Gesneriaceae memiliki spertura 3 - 4 colporate dengan bentuk subprolate sampai prolate. Hydrangea macrophylla dari familia Hydrangeaceae memiliki karakteristik morfologi polen unit monad, bentuk sub-prolate dengan ukuran kecil, memiliki tipe apertura tricolpate dan ornamentasi psilate. Sesuai dengan Gang \& Qiming (1996) bentuk butir serbuk sari sebagian besar spesies hydrangeaceae adalah sub-spheroidal sampai sub-prolate dengan aperture tricolpate atau tricolporate.

Trimezia longifolia dari familia Iridaceae memiliki unit polen monad, bentuk prolate dengan ukuran sedang, tipe aperture monocolpate dan tipe ornamentasi psilate. Sesuai dengan Erdtman (1952), polen familia Iridacee memiliki tipe apertura monosulcate/monocolpate, ukuran sekitar 35-120 $\mu \mathrm{m}$, dengan bentuk prolate sampai spheroidal. Terdapat 2 spesies anggota familia Lamiaceae yang ditemukan di sekitar sarang, yaitu Salvia splendens dan Clerodendrum thomsoniae. Menurut Sudarmono \& Sahromi (2012) polen familia Lamiaceae umumnya memiliki tipe apertura $3-8$ (colpate), jarang kolporat (colporate). S. splendens karakteristik morfologi polen berupa unit monad, bentuk prolate-spheroidal dengan ukuran besar, tipe apertura hexacolpate dan tipe ornamentasi bireticulate. Clerodendrum thomsoniae memiliki polen dengan unit monad, bentuk sub-prolate, ukuran besar, tipe apertura tricolpate dan tipe ornamentasi reticulate.

Cuphea hyssopifolia dari familia Lythraceae memiliki karakteristik morfologi polen berupa unit polen monad, bentuk prolate-spheroidal dengan ukuran kecil, tipe apertura tricolporate dan tipe ornamentasi psilate. Erdtman (1952) menyatakan bahwa polen familia lythraceae memiliki bentuk oblate - subrolate, aksis terpanjang 17-76 $\mu \mathrm{m}$, tipe apertura tricolporate. Tibouchina urvilleana dari 
familia Melastomataceae memiliki polen dengan unit polen monad, bentuk sub-prolate dengan ukuran kecil, tipe apertura monosulcate dan tipe ornamentasi psilate. Menurut Erdtman (1952), polen familia Melastomataceae memiliki bentuk spheroidal-prolate dengan panjang aksis 11-33 $\mu \mathrm{m}$, tipe aperture tricolporate. Zea mays dari familia Poaceae memiliki polen dengan unit monad, bentuk prolate spheroidal, ukuran besar, tipe apertura monoporate dan tipe ornamentasi scabrate. Menurut Erdtman (1952) polen familia Poaceae memiliki bentuk prolate - spheroidal, dengan ornamentasi psilate atau reticulate.

Persicaria capitata dari familia Polygonaceae memiliki polen dengan unit monad, bentuk spheroidal, ukuran kecil, tipe apertura tricolporate dan tipe ornamentasi echinate. Menurut Erdtman (1952) menyatakan bahwa polen dari familia Polygonaceae memiliki bentuk polen oblate spheroidal-prolate, aksis terpanjang 16-79 $\mu \mathrm{m}$ dengan aperture 3-4 colporate, polyporate, 8colpate. Rosa sp. dari familia Rosaceae meiliki karakteristik morfologi polen yaitu unit monad, bentuk prolate, ukuran sedang, tipe apertura tricolporate dan tipe ornamentasi psilate. Sesuai dengan Hebda, et al., (1988) anggota suku Rosaceae memiliki unit polen monad, dengan bentuk oblate hingga prolate, memiliki aperture yang beragam mulai tricolporate/colpate sampai polycolporate/colpate serta ornamentasi psilate hingga verrucate. Tropaeolum majus dari familia Tropaeolaceae memiliki unit polen monad, bentuk prolate-spheroidal, ukuran sedang, tipe apertura tricolporate dan tipe ornamentasi psilate. Menurut Erdtman (1952), anggota familia Tropaeolaceae memiliki karakter morfologi polen yaitu aperture triolporate, bentuk suboblate - spheroidal.

Berdasarkan hasil pengamatan karakter morfologi polen dari sarang lebah Trigona sp. didapatkan 12 jenis polen yang berbeda, 10 diantaranya teridentifikasi sebagai polen dari spesies Brassica sp., Daucus carota, Begonia cucullata, Rosa sp., Chrysosthemis pulchella, Tropaelum majus, Salvia spledens, Zea mays, Tagetes erecta dan Praxelis clematidea sedangkan 2 polen lainnya tidak teridentifikasi (Tabel.1).

Berdasarkan hasil pengamatan, ukuran dan bentuk polen yang dibawa oleh lebah Trigona ke dalam sarang sangat beragam. Ukuran polen terkecil adalah polen dari Rosa sp. Yaitu, sedangkan terbesar polen Salvia splendens, hal ini didukung oleh pernyataan Sulistia et al. (2018) bahwa Trigona tidak mengambil polen berdasarkan ukurannya, namun berdasarkan jarak bunga dengan sarang, aroma, dan warna bunga. Menurut Rustam \& Agus (2018) warna bunga, menjadi salah satu faktor penarik bagi serangga pollinator. Barth, (1991) menyatakan bahwa spektrum warna pada lebah adalah ultraviolet, biru dan kuning sehingga lebah cenderung mengunjungi bunga dengan warna-warna tersebut. Sedangkan untuk bentuk bunga, lebah madu lebih cenderung mendatangi bunga yang bentuknya terbuka atau bentuk bunga yang memudahkan bagi lebah madu untuk mengambil ectar atau polen (Yanto et al., 2016).

Lebah Trigona biasanya mengunjungi bunga dengan bermacam ukuran, namun lebih banyak pada bunga yang memiliki corolla kecil dan panjang (Ramadani, 2016). Karena ukuran tubuh yang kecil maka memungkinkan lebah Trigona tetap ect mengambil ectar atau polen dengan memasukkan kepala dan sebagian tubuhnya ke dalam tabung bunga untuk mengambil polen. (Khairiah et al., 2012). Selain itu, Lebah Trigona menyukai bunga yang memiliki simetri bilateral, simetri ini disukai oleh serangga karena bentuk simetri bilateral ini mempunyai landasan (landing pad) untuk pendaratan serangga (Khairiah et al., 2012).

Lebah Trigona mencari polen pada bunga yang sedang mekar di sekitar lokasi sarang (Michener 1974). Kesepuluh tanaman yang ditemukan polennya di dalam sarang merupakan tunbuhan yang berbunga sepanjang tahun, atau tumbuhan yang ditanam sepanang tahun. Jenis tumbuhan perkebunan yang ditanam sepanjang tahun diantaranya Brassica juncea, Daucus carota dan Zea mays. B. juncea memiliki bunga berukuran kecil berwarna kuning, Tumbuhan ini berjarak $\pm 72 \mathrm{~m}$ dari sarang lebah Trigona. D. carota memiliki bunga majemuk yang berukuran kecil, berwarna putih, tersusun memayung, arak tumbuhan dari sarang yang cukup dekat yaitu $\pm 41 \mathrm{~m}$. Z. mays memiliki bunga yang tersusun dalam bulir, berwarna kuning, ditemukan pada jarak $\pm 41 \mathrm{~m}$ dari sarang.

Jenis tumbuhan perennial atau yang berbunga sepanjang tahun diantaranya Chrysosthemis pulchella memiliki bunga dengan ukuran kecil, corolla berwarna kuning cerah, ditemukan berada dekat dari sarang yaitu pada jarak $\pm 12 \mathrm{~m}$. Begonia cucullata memiliki bunga berukuran kecil berwarna putih dan merah muda ditemukan berada $\pm 15 \mathrm{~m}$ dari sarang. Rosa sp. memiliki bunga berwarna merah dan bentuk bunga terbuka. Jarak dari sarang $\pm 72 \mathrm{~m}$. Salvia splendens memiliki tipe bunga tandan, berukuran kecil, berwarna merah terletak \pm $10 \mathrm{~m}$ dari sarang. Tropaeolum majus memiliki bunga dengan corolla berwarna merah, bagian dalamnya berwarna kuning. ditemukan pada jarak \pm $144 \mathrm{~m}$ dari sarang. Cleome houtteana memiliki bunga dengan struktur terbuka, berwarna ungu, Tumbuhan ini memiliki jarak dekat dengan sarang \pm $5 \mathrm{~m}$. sehingga sangat mudah dijangkau oleh lebah dekat dari sarang yaitu pada jarak $\pm 12 \mathrm{~m}$. Begonia cucullata memiliki bunga berukuran kecil berwarna putih dan merah muda ditemukan berada $\pm 15 \mathrm{~m}$ dari sarang. 
Tabel 1. Perbandingan polen dari bunga di sekitar sarang dan di dalam sarang

\begin{tabular}{|c|c|c|c|}
\hline No. & Spesies & Polen dari bunga sekitar sarang & Polen dari dalam sarang \\
\hline 1. & Brassica sp. & & \\
\hline 2. & Daucus carota & & \\
\hline 3. & Begonia cucullata & & \\
\hline 4. & Rosa sp. & & \\
\hline 5. & $\begin{array}{l}\text { Chrysosthemis } \\
\text { pulchella }\end{array}$ & & \\
\hline 6. & Tropaelum majus & & \\
\hline 7. & Salvia splendens & & \\
\hline 8 & Zea mays & & \\
\hline 9 & Tagetes erecta & & \\
\hline 10 & Praxelis clematidea & & \\
\hline 11 & Tidak Teridentifikasi & - & \\
\hline
\end{tabular}


Jenis tumbuhan perennial atau yang berbunga sepanjang tahun diantaranya Chrysosthemis pulchella memiliki bunga dengan ukuran kecil, corolla berwarna kuning cerah, ditemukan berada Rosa sp. memiliki bunga berwarna merah dan bentuk bunga terbuka. Jarak dari sarang $\pm 72 \mathrm{~m}$. Salvia splendens memiliki tipe bunga tandan, berukuran kecil, berwarna merah terletak $\pm 10 \mathrm{~m}$ dari sarang. Tropaeolum majus memiliki bunga dengan corolla berwarna merah, bagian dalamnya berwarna kuning. ditemukan pada jarak $\pm 144 \mathrm{~m}$ dari sarang. Cleome houtteana memiliki bunga dengan struktur terbuka, berwarna ungu, Tumbuhan ini memiliki jarak dekat dengan sarang $\pm 5 \mathrm{~m}$. sehingga sangat mudah dijangkau oleh lebah Trigona. Ditemukan polen dari dua spesies anggota familia Asteraceae yaitu Tagetes erecta dan Praxelis clematidea. $T$. erecta memiliki struktur bunga marginal bentuk pita, serta bunga cakram bentuk tabung. Bunga marginal berwarna merah dan bunga cakram berwarna kuning cerah, bentuk bunga terbuka. Sedangkan P. clematidea memiliki bunga majemuk berwarna ungu yang tumbuh diujung (Veldkamp, 2015). T. erecta ditemukan pada jarak \pm $144 \mathrm{~m}$ sedangkan $P$. clematidea ditemukan pada jarak \pm 153 m dari sarang lebah Trigona .

Hasil penelitian juga ditemukan morfologi polen yang tidak memiliki kecocokan dengan polen bunga disekitar sarang Lebah (Tabel 1. No 11). Polen tersebut memiliki karakterisrik unit polen monad, bentuk polen spheroidal, ukuran besar, tipe apertura pericolpate dan tipe ornamentasi baculate. Hal ini dimungkinkan karena lokasi bunga yang berada diluar radius pengamatan, lebah Trigona sendiri memiliki jarak terbang mencapai $500 \mathrm{~m}$ dari sarang (Pratama et al., 2018), namun biasanya lebah Trigona lebih cenderung mencari pakan dari tumbuhan yang dekat dari sarang nya (Nugroho \& Soesilohadi, 2014).

\section{SIMPULAN}

Karakter polen dari 23 bunga yang terdapat diluar sarang Trigona bervariaasi. Morfologi pollen yang terbawa di sarang Trigona memiliki kemiripan dengan 10 spesies tumbuhan yang ada di luar sarang.

\section{DAFTAR REFERENSI}

Agussalim, A. A., Umami, N., dan Budisatria, I.G.S. 2017. Variasi Jenis Tanaman Pakan Lebah Madu Sumber Nektar dan Polen Berdasarkan Ketinggian Tempat Di Yogyakarta. Jurnal Buletin Peternakan, 41(4), pp. 448-460.

Azizah, N., Suedy, S. W. A., dan Prihastanti, E. (2016). Keanekaragaman Tumbuhan Berdasarkan Morfologi Polen dan Spora dari Sedimen Telaga Warna Dieng, Kabupaten Wonosobo, Jawa Tengah. Buletin Anatomi dan Fisiologi Dh Sellula, 24(1), pp. 66-75.
Backer, C. A. and Brink, R. C. B. V. D. 1968. Flora of Java (Spermatophytes only) Vol. III. Groningen. The Netherlands: Wolters.Noordhoff. N.V.

Barth, FG., 1991. Insect and Flowers: The Biology of Partnership. New Jersey: Princeton University Press.

Das, S.K., and Mukherjee, S.K. 2013. Comparative Morphological, Anatomical and Palynological Observation in Ageratum conyzoides and Ageratum houstonianum of the Family Compositae. Research Article, 2 (4), pp. 48-62.

Erdtman, G. 1952. Pollen Morphology and Plant Taxonomy Angiospermae (An Introduction to Palinology I). Sweden: Almquist \& wiksells.

Faegri, K. and J. Iversen, 1989. Textbook of Pollen Analysis. New York: Hafner Press.

Gang, H. and Qiming, H. 1996. A Study of Pollen Morphology of Hydrangeoideae (Hydrangeaceae). Journal of Tropical and Subtropical Botany, 4(3), pp. 26-31.

Haryanto, A.A. 2017. Analisis Tataniaga Stroberi (Vragaria vesca) Pendekatan Structure, Conduct, Performance (SPC) di Desa Serang, Kecamatan Karangreja, Kabupaten Purbalingga. Skripsi. Universitas Muhammadiyah Purwokerto.

Hebda, R.J., Cinnapa, C.C and Smith, B.M. 1988. Pollen morphology of the Rosaceae of Western Canada. Grana, 27, pp. 95-113.

Kapp, R.O. 1969. How to Know Pollen and Spores. Lowo: W.M.C. Brown Company Publishers Dubuque.

Khairiah, N., Dahelmi dan Syamsuardi. 2012. JenisJenis Serangga Pengunjung Bunga Pacar Air (Impatien balsamina Linn.: Balsaminaceae). Jurnal Biologio Universitas Andalas, 1(1), pp. 9-14.

Michener, C.D. 1974. The Social Behavior of the Bees. Cambridge (USA): Harvard University Press.

Moore, P.D., J.A. Webb and M.E. Collinson. 1991. Pollen Analysis. England: Blackwell Scientific Publication, Oxford.

Nugroho, R.B. dan Soesilohadi, H.R.C. 2014. Identifikasi Macam Sumber Pakan Lebah Trigona sp (Hymenoptera: Apidae) di Kabupaten Gunungkidul. Biomedika, 7(2), pp. 42-45.

Perveen, A. 1999. Contributions to the Pollen Morphology of the Family Compositae. Tr. Journal of Biology, 23, pp. 523-535.

Pratama, I. P. N. E., Watiniasih, N. L dan Ginantra I. K. 2018. Perbedaab Ketinggian Tempat Terhadap Jenis Polen yang Dikoleksi Oleh Lebah Trigona. Jurnal Biologi Udayana, 22(1), pp. 42-48. 
Ramadhani, R. F. 2016. Keanekaragaman Polen dari Beberapa Spesies Stringles Bee pada Perkebunan Kelapa Sawit dan Karet. Tesis. Bogor: Institut Pertanian Bogor.

Rismayanti, Triadiati dan Raffiudin, R. 2015. Ecology Service Tumbuhan Herba untuk Lebah Trigona sp. Jurnal Sumberdaya Hayati, 1(1), pp. 19-25.

Rustam, E. dan Agus A. P. 2018. Morfologi dan perkembangan bunga-buah tembesu (Fragraea fragrans). Pros Sem Nas Masy Biodiv Indon, 4(1), pp. 13-19.

Steenis, V. C.G.G.J. 1987. Flora. Jakarta: Pradnya Paramita.

Sudarmono \& Sahromi. 2012.Pollen atau Serbuk Sari: Aspek Morfologi, Sistematika dan Aplikasinya Pada Tumbuhan Keluarga Mentol. Jurnal Sains Natural Universitas Nusa Bangsa, 2(1), pp. 12-16.

Sukarsa, Pudjoarinto, A. dan Utami, N. 2002. Morfologi dan Nilai Taksonomi Serbuksari Impatiens (Balsaminaceae). Floribunda, 2(1), pp. 1-5.
Sulistia, M.L., S. Latifah., Irwan M. L. A, dan Dwi S. R. 2018 Identifikasi Jenis Polen Sebagai Sumber Pakan Lebah Trigona (Trigona clypearis) di Lahan Agroforestri. Tesis. Program studi kehutanan, Universitas Mataram, Mataram.

Tjitrosoepomo, G. 2002. Morfologi Tumbuhan. Yogyakarta: Gadjah Mada University Press.

Veldkamp, J. 2015. Praxelis clemidae. Gardens.Bulletin Singapore. 51, pp. 119-124.

Widhiono, I., Eming S., Edy T. dan Darsono. 2016. Keragaman Serangga Penyerbuk di Lereng Gunung Slamet dan Sekitarnya. Purwokerto: Universitas Jenderal Soedirman.

Wulandari, A.P., Atmowidi, T. dan Kahono, S. 2017.Peranan Lebah Trigona laeviceps (Hymenoptera: Apidae) dalam Produksi Biji Kailan (Bressica oleracea var. alboglabra). J Agron Indonesia, 45(2), pp. 196-203.

Yanto, S.H., Defri Y, dan Evi S.B. 2016. Potensi Pakan Trigona spp. di Hutan Larangan Adat Desa Rumbio Kabupaten Kampar. JOM Faperta, 3(2), pp. 1-7. 